\title{
Tarihi Bir Vesikanın İncelenmesi Üzerine Bir Deneme: Erivan Murahhası Yüzbaşı Bahaeddin Bey'in Raporu
}

\author{
Güzin Çaykıran* \\ (ORCID: 0000-0002-8524-8405) \\ Makale Gönderim Tarihi \\ 28.01.2021 \\ Makale Kabul Tarihi \\ 29.03.2021
}

\section{Atıf Bilgisi/Reference Information}

Chicago: Çaykıran, G., "Tarihi Bir Vesikanın İncelenmesi Üzerine Bir Deneme: Erivan Murahhası Yüzbaşı Bahaeddin Bey'in Raporu", Vakanüvis-Uluslararası Tarih Araştırmaları Dergisi, 6/1 (2021): 76-97.

APA: Çaykıran, G. (2021). Tarihi Bir Vesikanın İncelenmesi Üzerine Bir Deneme: Erivan Murahhası Yüzbaşı Bahaeddin Bey'in Raporu. VakanüvisUluslararası Tarih Araştırmaları Dergisi, 6 (1) , 76-97.

\section{Öz}

Tarih ilminin yegâne gayesi, tarihte doğruyu yanlıştan ayırmaktır. Bunun için takip edilen başlıca yöntem tarihi vesikalar üzerinde tarihin dış ve iç tenkit unsurlarını uygulamaktır. Böylece elde edilen tarihi bilginin doğrulanabilirliği de sağlanmış olmaktadır. Bilindiği üzere tarih, doğrudan olguların kendisine ulaşmaz, onları vesikaları çerçevesinde ele alır. Bu vesikalar da belirli usul ve yöntemlerle incelendikten sonra tarih ilminin birer parçası haline gelir. Bu kapsamda çalışmada Erivan Türk Mümessilliğinden Yüzbaşı Bahaeddin Bey tarafından Şahtahtı Müfrezesine gönderilmiş olan bir rapor incelenmiştir. Söz konusu raporun incelenmesinde tarih tenkidinin unsuları; dış ve iç tenkit yöntemi takip edilmiştir. Dış tenkit unsurları kapsamında raporun tarihi, yazarı, yeri, raporun nereden (hangi makamdan) çıktığı ve alan makamı tespit edilmiştir. iç tenkitte ise yazarın ve vesikada geçen olayların tenkidi yapıımışırı. Böylece raporda geçen olayların dönemin olaylarını yansıtıp yansıtmadığı tespit edilmeye çalışılmıştır. Çalışmada örneklem olarak ATASE

*Dr., ATASE Arşivi, guzincaykiran@gmail.com.

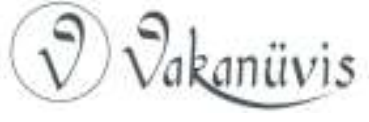


Arşivi İstiklal Harbi Koleksiyonundan bir vesika seçilmiştir. Vesikanın seçilmesindeki başlıca amaç, vesikada geçen bilgilerin çeşitliliği ve dönemin Ermenistan'ı hakkında bilgiler sunmasıdır. Söz konusu bilgiler, nitel yöntemle ele alınmış ve literatürde yer alan bilgiler çerçevesinde vesikada geçen konulara açıklık getirilmiştir.

Anahtar Kelimeler: Tarih İlmi, İç ve Dış Tenkit Unsurları, Erivan Türk Mümessilliği, Yüzbaşı Bahaeddin Bey, Ermeniler.

\section{A Review of a Historical Document: A Report by Captain Bahaeddin Bey, Member of the Turkish Delegate to Yerevan}

\section{Abstract}

The most distinctive objective of the discipline of history is to distinguish the right from wrong in history. The principal method pursued to this end is the application of the peripheral and contextual elements of criticism on the historical documents. Thus, the authenticity of historical information can be verified. It is evident that history does not directly reach the incidents but scrutinizes them within the context of the pertinent documents. Documents become parts of the discipline of history following a close examination subject to certain procedures and methods. In this study the report Captain Bahaeddin Bey, a member of the Turkish Delegation at Yerevan, wrote to Shahtaxtı Platoon is scrutinized. In the analysis of the mentioned document elements of historical criticism - external and internal means of criticism have been exploited. Within the context of external elements, the date it was written, writer, the place the report was written, competent authority writing the document and the receiving authority are determined. As for the contextual analysis, criticism of the report writer and the incidents mentioned in the report are made. Hence, whether the incidents mentioned reflected the current state of affairs is tried to be determined. A sample document from the Turkish National War of Sovereignty Collection at the ATASE Archive is chosen. The primary reason in choosing this document is its embodying of informational diversity and presenting of information on Armenia then. Mentioned information is studied through qualitative method, and the issue is clarified by exploiting the information available in relevant literature.

Keywords: Discipline of History, Elements of peripheral and contextual elements, Turkish Delegation to Yerevan, Captain Bahaeddin Bey, Armenians.

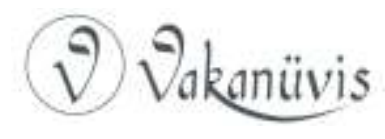




\section{Giriş}

Tarih ilminin disiplinler arasında yer almasını sağlayan başlıca âmil, bilgiye ulaşmak için belirli bir metodun takip edilmesidir. Bunun için öncelikle şahitlikleri araştırmak, onları kontrol etmek ve nihayetinde onları anlamak ve anlamlandırmak gerekmektedir. ${ }^{1}$ Bu sayede tarihi bilginin doğruluk derecesinin sorgulanabilirliği (kontrol tarzının ciddiliği) $^{2}$ de sağlanmış olmaktadır. Bu sorgulama, tarih ilmi içerisinde dış tenkit ve iç tenkit unsurlarıyla gerçekleştirilmektedir. Dış tenkit metodu ile eserin [veya vesikanın] künyesi, kaynak tahlili ve vesikanın tenkidi (diplomatik tenkit) yapılırken iç tenkit ile yazarın tenkidi ve anlatılan olayların tarihi döneme uygunluğu sorgulanmaktadır. ${ }^{3}$ Nitekim tarih metodu, herhangi bir olayı, devrin iç ve dış koşullarından soyutlayarak değerlendirmeyi kabul etmemektedir. ${ }^{4}$ Dolayısıyla ortaya koyulan herhangi bir bilgi, tek başına bir şey ifade etmemektedir. Böylece tarihi bir bilginin doğrulanabilirliği (sahihliği) ve bilginin ortaya koyduğu bulguların değerlendirilmesi için dönemin şartlarına vakıf olmak bir zorunluluk haline gelmektedir. Bundan yola çıkarak 16 Mart 1921 'de Erivan Murahhası Yüzbaşı Bahaeddin Bey tarafından Şahtahtı Müfreze Kumandanlığına gönderilmiş olan raporun doğrulanabilirliği; iç ve dış tenkit unsurları da dâhil olmak üzere Rusya, Türkiye ve Ermenistan'da yaşanan olayların îzâhına ve bu olayların raporda geçen bilgilerle paralellik gösterip göstermediğine bağlıdır. ${ }^{5}$ Dolayısıyla raporda sunulan her bir bilginin epistemolojik olarak aydınlatılması belgenin doğrulanabilirliğine katkı sağlayacaktır.

Çalışmanın ana konusu, tarihi bir vesikanın iç ve dış tenkit metoduyla nasıl yorumlanabileceği üzerinedir. Bu çalışmada birçok tarihi vesikayı evren olarak incelemek mümkün olmadığından Erivan

\footnotetext{
1 Leon-E. Halkın, Tarih Tenkidinin Unsurları, Çev. Bahaeddin Yediyıldız, Türk Tarih Kurumu Yayınları, Ankara, 2014, s.3.

${ }^{2}$ Halkın, a.g.e., s.7.

3 Mübahat S. Kütükoğlu, Tarih Araştırmalarında Usul, Türk Tarih Kurumu Yayınları, Ankara, 2014, s. 28-35.

4 Mehmet Akif Tural, “ikinci Dünya Savası Sırasında ve Bitişinde Türkiye'nin Ekonomisi", Prof.Dr.Abdurrahman Güzel Armağanı, Akçağ, 2013, s.154.

${ }^{5}$ Dönem itibariyle Rusya'da 1917 Bolşevik Ihtilali'nin gerçekleşmesiyle birlikte iç savaş sürmektedir. Türkiye, Yunanistan ile savaş halinde, Ermenistan ise Bolşevik ordusu tarafından işgal edilmiş durumdadır.
}

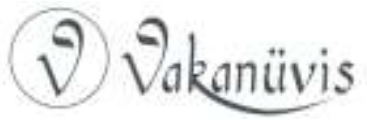


Murahhası Yüzbaşı Bahaeddin Bey'in Şahtahtı Müfrezesine gönderdiği rapor, örneklem olarak seçilmiştir. Nitel yöntem ile örneklem seçilen vesikada geçen birçok bilgi, ayrıntılı bir şekilde analiz edilerek aydınlatılmaya çalışılmışır. Analiz sonucunda ise tarihi bir vesikanın doğrulanabilirliği çabası içerisinde, dönemin koşullarına dair vesikadan hangi bilgilere ulaşıldığı ortaya konulmuştur. İncelenecek tarihi vesikanın transkripsiyonu şöyledir:

Şahtahtı Müfreze K.

Gayet Aceledir (Çok ivedi)

lğdır

13-14 gecesi perhiz [oruç] münasebetiyle Kamerli'de Ermeniler biraz fazla içmişler ve içlerinde bulunan bir Bolşevik Ermeni, bunların halini derhal Bolşevik mıntıkasına haber vermiş ve bir baskınla bulundukları Kamerli'yi zabt etmişlerdir. Bu ilk raporumdur. Sehven arz ettiğim gibi iki top değil, iki topun kamaları götürülmüştür. Hükümet, yetmiş yaşına kadar silahaltına çağırıyor. Bu tebligata biraz mukavemet gösteren Türkiye Ermenileridir. Türk ve Rus Ermenileri arasındaki ihtilaf hemen gözükür bir şekle girmiştir ki istifade edeceklerini tahmin ediyorum. Müslümanlarda şehrin muhafazası için her evden bir adam vermeye davet edilmişlerdir. Dükkânların kısm-ı azamı [çoğu] kapalıdır. Maneviyat pek bozuktur. Nahçıvan telsizinin Nahçıvan'da mukabil inkılap başladığı haftada Bakü'ye verdiği bir haber, bura telsizi tarafından çalınmış bununda gazetelerle ilanı maneviyatı biraz takviye etmiştir. Şehirde ekmek et bulunmuyor. Hükümet cevab-ı zazuriyeye tarh [vergi] koymuş ve bundan dolayı her şeyi gizlemiştir. Mamafih, hali tabii avdet etmesiyle Ermenistan kendisini iki ay beslemeyebilir. Bu sene ziraatta muntazam olamayacağından müthiş bir kıtlık hüküm ferma olacağını zan ediyorum. Burada pek mebzul (bol) olan pirinç bir putı (ölçü birimi) bir ay evvel 70.000 ruble iken bugün 250.000 rubleye çıkmıştır. Bir kont [ölçü birimi] gaz 3.000 rubledir. Bütün ümit Nahçıvan yolunun açılmasında ve Türkiye'nin muavenetindedir. Türkiye Ermenileri Sevr'e göndermeleri için müracaat etmekte [şifrelenmiş] unuttukları 
Osmanlı tebaası [şifrelenmiş] kemal-i iftiharla [şifrelenmiş] Sevr'e bakmaktadırlar. ${ }^{6}$

16.3.1337/16.03.1921

Murahhas Bahaeddin

\section{Tarih Tenkidinin Unsurları Kapsamında Vesikanın İncelenmesi}

Dış tenkit unsurları dâhilinde raporun tarihi, yazarı, yeri, raporun nereden (hangi makamdan) çıktığı ve alan makamı mevcuttur. Buna göre rapor, Erivan Murahhası Bahaeddin Bey tarafından 16 Mart 1921 tarihinde Iğdır'dan Şahtahtı Müfrezesi'ne gönderilmiştir. Müfreze, 1920 'de 15. Kolordu (Erzurum) Kumandanı Kâzım Karabekir Paşa tarafından Nahçıvan/Şahtahtı'na gönderilmiş olup müfrezenin teşkilatında 11'inci Kafkas Tümeni'nin 34. Alayının 1. Taburu ile bir makineli tüfek bölüğü ve bir koşulu batarya bulunmaktadır. Söz konusu müfreze, 1920'de Ermenilere karşı harekât yürütmüştü. ${ }^{7}$ Raporu gönderen makam, Erivan Türk Mümessilliğidir (Erivan Türk Temsilciliği). Bahaeddin Bey'de temsilcilikte çalışan askerî bir murahhastır (murahhasiyyet). ${ }^{8}$ Söz konusu temsilcilik, Ermenistan Cumhuriyeti ile Osmanlı Devleti arasında 31 Mayıs 1918'de imzalanan Barış ve Dostluk Antlaşması gereğince kurulmuştu. Bu bağlamda Ermenistan Osmanlı Mümessilliğine askerî temsilci olarak Ferik Mehmet Ali Paşa ${ }^{9}$ ve yardımcı olarak da Kars Şehbenderi Celaleddin Bey atanmıştı. ${ }^{10}$ Bunların yanı sıra rapor Erivan'dan değil, Iğdır'dan gönderilmiştir. Zira Iğdır, raporun tarihi (16 Mart 1921) itibariyle

\footnotetext{
${ }^{6}$ MSB ATASE Arşivi, İstiklal Harbi Koleksiyonu (iSH), Kutu: 1022, Gömlek: 113 (Ek-1).

${ }^{7}$ Ali Arslan, "I. Dünya Savaşı Sonunda Nahçıvan'da Yapılan Milli Mücadele ve Bugünkü Nahçıvan'ın Statüsünün Oluşumu", Atatürk Araştırma Merkezi Dergisi, XIV/41 (Temmuz 1998), s.537.

${ }^{8}$ Murahhas: Delege, bir devlet veya teşekkül, bir kurum adına salahiyetli olarak bir yere, birinin makamına gönderilen kimsedir, murahhasiyyet ise murahhaslık, delegeliktir. Ferit Develioğlu, Osmanlıca-Türkçe Sözlük, Aydın Kitabevi, Ankara, 2002, s.684.

9 Ömer Turan, “Bolşevik intilali’ni Takip Eden Günlerde Kuzey Kafkasya'da Bağımsızlık Hareketleri ve Yusuf Ercan'ın Sohum Müfrezesi Hatıraları”, Askeri Tarih Bülteni, 40 (1996), s.140-141.

10 BOA, HR-HMŞ-işo,231-80-1-1(5 Ağustos 1918).
}

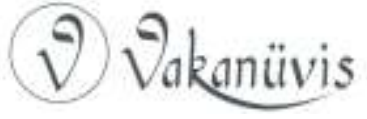


Türkiye'ye ait bir toprak parçasıdır. ${ }^{11}$ Dolayısıyla Bahaeddin Bey'in, Erivan'a yakın bölgeleri dolaşarak bilgiler topladığı ve Ermenistan bölgesi hakkında Şahtahtı'nda bulunan Türk müfrezesine bilgiler verdiği anlaşılmaktadır. Rapor, numarasız olarak gönderilmiştir. Bunun iki sebebi olabilir; raporda geçen ilk raporum ibaresi dikkate alınırsa bu rapor, ilk gönderilen raporun düzeltilmiş tekrarı olabilir. Diğer bir sebebi de raporun istihbarî bilgiler içermesi bakımından kayıt altına alınmak istenmemiş olabileceğidir. Bilindiği üzere, kamu dâhilinde olan bütün yazışmalarda evrakın çıktığı birim tarafından evraka bir numara verilmektedir. Bu evrak numarası ile evrak kayıt altına alınmaktadır.

11 Bu Türk bölgesi, 2 Aralık 1920'de Gümrü Antlaşması ile birlikte Anavatan'a katılmıştır. Tevfik Bıyıklıoğlu, Osmanlı-Türk Doğu Hudut Politikası, Milli Savunma Akademisi (Basılmamış daktilo eser ATASE Kütüphanesi), İstanbul, 1958, s.12. 


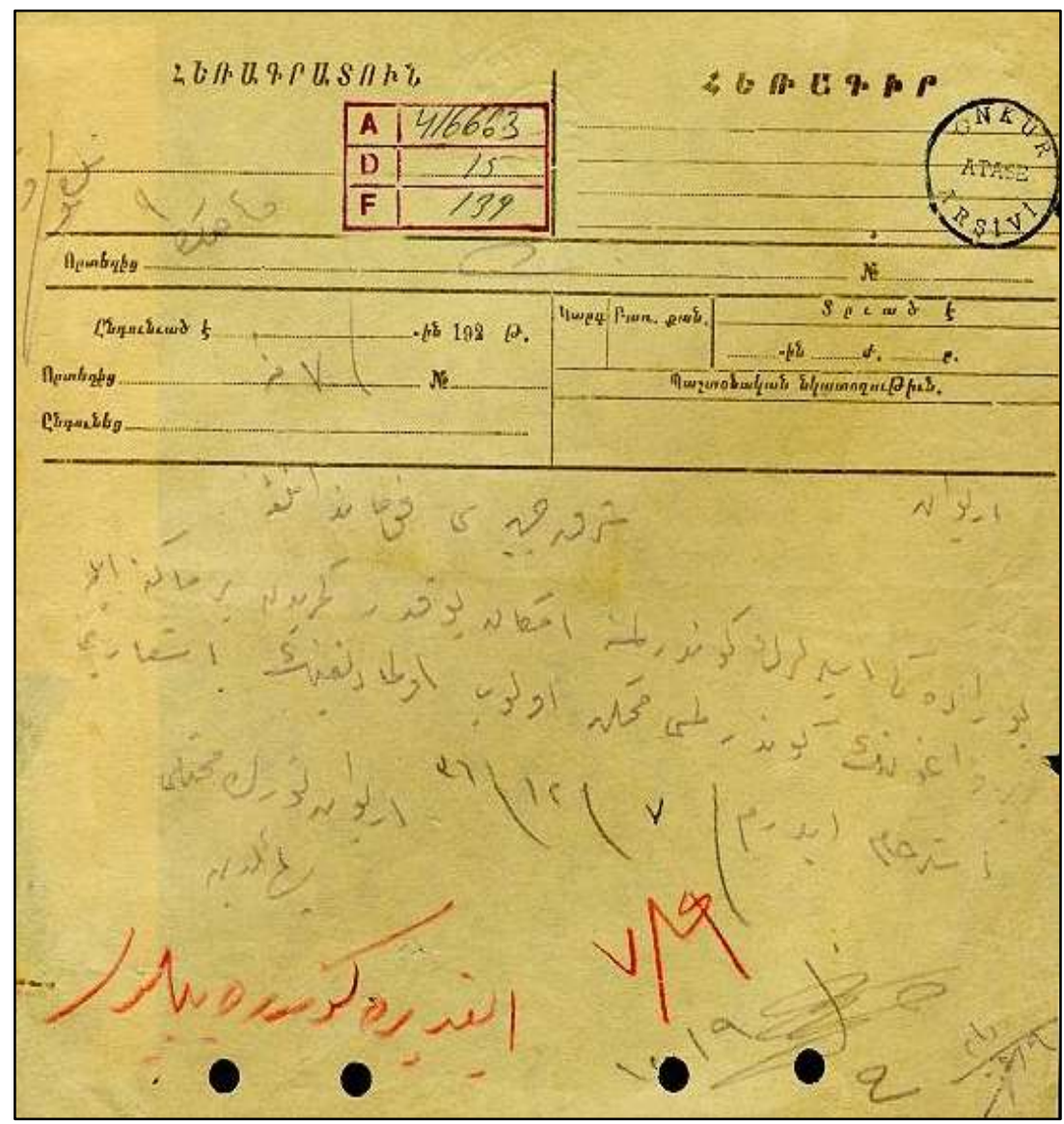

Vesika-1 Bahaeddin Bey'in Erivan'dan Şark Cephesi Kumandanlığına gönderdiği bir telgrafi ${ }^{12}$

Vesikanın iç tenkit unsurları içerisinde yer alan müellifin tenkidi kapsamında Yüzbaşı Bahaeddin Bey'e dair henüz bir vesikaya ulaşılamamıştır. Fakat Yüzbaşı Bahaeddin Bey tarafından gönderilen

12 Belgenin içeriği şöyledir: Buradaki [Erivan'a] ailelerin gönderilmesine imkân yoktur. Kamerli'ye bir makine ile bir vagonun gönderilmesinin mümkün olup olmadığının işarını istirham ederim. Erivan Türk Mümessili Bahaeddin, 7 Aralık 1920. Kırmızı ile yazılmış notta ise, "Iğdır’a gönderilebilir" notu düşülmüştür. MSB ATASE Arşivi, İstiklal Harbi Koleksiyonu (iSH), Kutu: 756, Gömlek: 77. 
çeşitli vesikalar bulunmaktadır. ${ }^{13}$ Dolayısıyla bu durum Bahaeddin Bey'in murahhaslık görevinde olduğunu kanıtlamaktadır. Örneğin Vesika 1'de görüldüğü üzere Bahaeddin Bey tarafından Şark Cephesi Kumandanlığına bir telgraf gönderilmiştir. Bahaeddin Bey bu telgrafta üzerinde Ermenice yazılar bulunan antetli bir kâğıt kullanmıştır. Dolayısıyla bu durum Bahaeddin Bey'in Ermenistan'da görev yaptığına dair bir kanıt niteliği taşımaktadır.

Aynı şekilde vesikanın iç tenkit unsurları içerisinde yer alan vesika içeriğinin, dönemin olayları ile tutarlı olup olmadığıdır. Bu durum vesikanın doğrulanabilirliğine katkı sağlamaktadır. Buna göre vesika içeriğinde geçen konulara kısaca açıklık getirmek gerekmektedir.

13-14 gecesi perhiz (oruç) münasebetiyle Kamerli'de Ermeniler biraz fazla içmişler ve içlerinde bulunan bir Bolşevik Ermeni, bunların halini derhal Bolşevik mıntıkasına haber vermiş ve bir baskınla bulundukları Kamerli'yi zapt etmişlerdir. Hükümet, yetmiş yaşına kadar silahaltına çağırıyor. Bu tebligata biraz mukavemet gösteren Türkiye Ermenileridir. Türk ve Rus Ermenileri arasındaki ihtilaf hemen gözükür bir şekle girmiştir $\mathrm{ki}$ istifade edeceklerini tahmin ediyorum. Müslümanlarda şehrin muhafazası için her evden bir adam vermeye davet edilmişlerdir.

Erivan Murahhası Yüzbaşı Bahaeddin Bey tarafından Şahtahtı Müfrezesine gönderilen raporun ilk kısmında Ermenilerin dini inancı, Ermenistan'ın yönetimi ve ideolojik durum ile Ermenistan'da yaşayan Müslüman Türk nüfusunun varlı̆̆ı hakkında çıkarım yapmak mümkündür. Buna göre Ermenilerin dini inancı şöyledir: Ermeniler Hıristiyan bir millet olup XIX. yüzyıla kadar Ermeni Apostolik (havarilere ait) Kilisesi'ne [Gregoryen] bağlıydı. Bu tarihten sonra ise misyonerlerin etkisiyle Katolik ve Protestan mezheplerine ayrılmışlardı. ${ }^{14}$ Ermenilerin iddiasına göre Hıristiyanlık, kendi topraklarına $\mathrm{Hz}$. İsa'nın iki havarisi Thaddeus ve Bartholomev tarafından getirilmişti. Yine iddiaya göre 301

13 MSB ATASE Arşivi, İstiklal Harbi Koleksiyonu, Kutu: 76, Gömlek: 64, Kutu: 760, Gömlek: 64aa, Kutu: 1022, Gömlek: 123.

${ }^{14}$ Abdurrahman Küçük, Ermeni Kilisesi ve Türkler, Ocak Yayınları, Ankara, 1997, s. $35-$ 36.

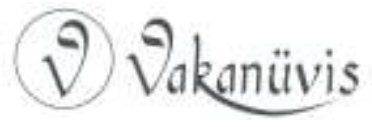


yılında Aziz Gregor ${ }^{15}$ sayesinde Ermeni Kralı Tridat, Hıristiyanlığı kabul etmiş ve Ermeniler de Hıristiyanlığı resmi devlet dini olarak kabul eden ilk toplum olmuştu. Ermeni Kilisesi'nin merkezi, Ermenistan'da bulunan Ecmiadzin(Vağarşabat)'dir. ${ }^{16}$ Eçmiadzin Kilisesi, Aziz Gregor tarafından kurulmuş ve ona milletin temsilcisi anlamına gelen Katogikos unvanı verilmiştir. Bugünkü kilise teşkilâtına göre iki katogikosluk bulunmaktadır: Ermenistan'da Ecmiadzin Gregoryen Katagikosluğu ile Lübnan'da Antilyas Gregoryen Katagikosluğu (Kilikya veya Sis Katagikosluğu). Hiyerarşik olarak Ecmiadzin Katagikosluğu bütün Ermenilerin dini merkezi durumunda olup Antilyas Katagikosluğu'nun üstü sayılmaktadır. Bunların yanı sıra iki de patrikhane mevcuttur. Bunlardan biri, İstanbul Kumkapı Gregoryen Ermeni Patrikhanesi, diğeri Kudüs Gregoryen Ermeni Patrikhanesi'dir. ${ }^{17}$ Nitekim bu bilgiler doğrultusunda Hristiyanlık geleneği içerisinde yer alan Paskalya Bayramı, Ermeniler tarafından da kutlanmaktadır. Buna göre raporda geçen perhiz(oruç), Paskalya öncesi yerine getirilen dini bir vazife ${ }^{18}$

15 Ermenilere göre Ermeni toplumunda din değiştirmenin öncüsü, Aziz Gregor'dur. Aziz Gregor, Ermenileri İncil'in Işığı ile aydınlattığı için kendisine Lusavoriç yani Aydınlatıcı lakabı verilmiştir. Aziz Gregor, o tarihten itibaren bu lakapla tanınmış ve kurmuş olduğu kilise de bu unvanla anılmıştır. Batılılar bu kiliseye Gregoryen Ermeni Kilisesi, Ermeniler ise Lusavorçagan Ermeni Kilisesi demektedir. Canan Seyfeli, "Surp Krikor Lusavoriç: Ermenilerin Aydınlatıcısı", Uluslararası Türk Dünyası Inanç Önderleri Kongresi, Ankara, (2002) s. 771-786.

${ }^{16}$ Ermenilerin iddiasına göre Eçmiadzin aynı zamanda Tanrı'nın Oğlu'nun şehridir, Aziz Gregor'a göre Tanrı'nın oğlu ( $\mathrm{Hz}$. İsa) cennetten buraya düşmüştür ve elindeki altın bir asma dalıyla gösterdiği yere dünyanın ilk Hıristiyan kilisesini kurmuştur. Sonra burası, Eçmiadzin olarak anılmaya başlanmıştır. http://www.officespace.am/Unuuulhn_ umnq/touhurohl/, [Erişim Tarihi: 22.01.2021]. Eçmiadzin'in diğer isimleri: (UЦuul

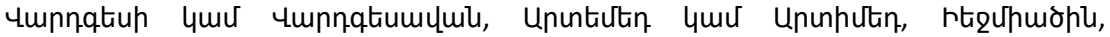

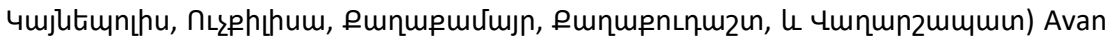
Vardgesi veya Vardgesavan, Artemed veya Artimed, lecmiadzin, Kaynepolis, Üçkilisa, Kağakamayr, Kağakudaşt ve Vağarşabat'tır. http://anitour.am/destinations. php?etchmiadzin, [Erişim Tarihi: 22.01.2021].

${ }^{17 Z e y n e p ~ I ̇ s k e f i y e l i, ~ " E r m e n i ~ K i m l i g ̆ i n i n ~ O l u s ̧ u m u n d a ~ D i n ~ F a k t o ̈ r u ̈: ~ H ı r i s t i y a n l ı k, ~ K i l i s e ~ v e ~}$ Misyonerler", Akademik Incelemeler Dergisi, Sakarya Üniversitesi, II/1 (2007) s. 235255.

${ }^{18}$ Paskalya; Hz. İsa'nın çarmıha gerilerek öldürüldükten sonra yeniden dirilişinin anıldığı bir bayramdır. Kutlama tarihleri 22 Mart-25 Nisan tarihleri arasında yıllara göre değişiklik göstermektedir. Ermeni toplumunda Surp Zatik adını alan bu bayram öncesinde Ermeniler, yedi hafta boyunca perhiz (oruç) yapmaktadır. "Paskalya ve Ermeniler", http://ermenikulturu.com/paskalya/, [Erişim Tarihi: 06.01.2021].

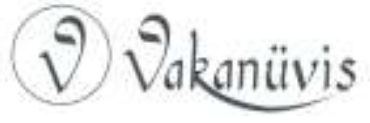


olup Ermenilerin 13-14 Mart gecesi, kutlama yaptıkları anlaşılmaktadır. Sonuç olarak raporda geçen dini vazife, tarih (date) bakımdan da doğrulanmış bir bilgidir.

Ermenistan'ın yönetim şekli ve ideolojisi hakkında ise şunları söylemek mümkündür: Rapora göre Kamerli'de ${ }^{19}$ bulunan Ermenilerin perhizde (oruç) oldukları sırada fazla içki içmeleri nedeniyle Bolşevik bir Ermeni tarafından Bolşevik idarecilere şikâyet edilmiş ve Kamerli, Bolşevik birlikleri tarafından zapt edilmiştir. Bilindiği üzere 1917 Bolşevik intilali ile başlayan Rusya iç savaşı, 1922 yılına kadar sürmüş ve katı bir disiplin içinde Bolşevik ideolojisi, Rus topraklarında yaşayan bütün topluluklara zorla kabul ettirilmeye çalışılmıştı. Bu bağlamda Kafkasya'ya doğru yayılan Bolşevik Rusya, 02 Aralık 1920'de Ermenistan Cumhuriyeti'ni işgal ederek Sovyet Sosyalist Hükümetini kurmuştu. Bu hükümet, Sovyet Rusya ve Ermenistan arasında 02 Aralık 1920 'de yapılan bir antlaşma ile göreve gelmişti. ${ }^{20}$ Antlaşmaya göre bu tarihten sonra Ermenistan Cumhuriyeti, Ermenistan Sovyet Sosyalist Cumhuriyeti adını almıştı. Dolayısıyla Ermenistan artık Bolşevik ideolojisi altında idare edilmeye başlanmıştı. ${ }^{21}$ Bu hükümetin başlıca görevi, halk içerisindeki Bolşevik muhalefete son vererek ideolojiyi yerleştirmekti. Bunun içinde Bolşevik Ermenistan Hükümeti, 70 yaşına kadar olan erkekleri silahaltına çağırmıştır. Bu çağrıya Osmanlı topraklarından gelen Ermeniler karşı çıkmış, Müslümanlar da her evden birer erkek vermek üzere davet edilmişlerdir. Raporda geçen Osmanlı topraklarından Ermenistan'a göç etmiş Ermenilerin bu çağrıya karşı çıkması, geldikleri Osmanlı coğrafyasının uzun yıllar (Osmanlı-Rus Savaşları, Osmanlı-italyan Savaşı, Balkan Savaşı, Birinci Dünya Savaşı, Türk ìstiklal Harbi) savaşlara sahne olması ile ilişkilendirilebilir. Öte yandan göç etmiş olan Ermenilerin, Ermenistan'ı henüz bir vatan olarak görme fikrinin veya hissiyatının zayıf olması ile açıklanabilir. Bunların yanı sıra rapora göre Ermenilerin, Rus Ermenileri

\footnotetext{
${ }^{19}$ Kamerli, bugün Ermenistan'da bir yerleşim yeridir, adı Artaşat olarak değiştirilmiştir. 20 "The History of Armenian Parliaments", https://web.archive.org/web/20160303173531/ http://www. Parliament.am/parliament.php?id=parliament\&lang=eng, Erişim Tarihi: 02.01.2021. ${ }^{21}$ Caner Çakı, "Ermenistan Sovyet Sosyalist Cumhuriyeti'nde Joseph Stalin Döneminde Kullanılan Sovyet Propaganda Posterleri Üzerine İnceleme", Ermeni Araştırmaları Dergisi, 61 (2018), s. 275.
}

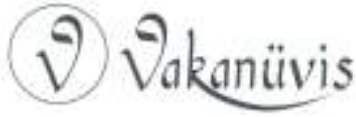


ve Osmanlı topraklarından göç etmiş Ermeniler olmak üzere iki gruba ayrıldığı anlaşılmaktadır(Türk Ermenisi, Rus Ermenisi). Rus Ermenilerinin, Türk Ermenisi olarak gördükleri Ermenileri, pek hoş karşılamadıkları görülmektedir. Zira Rus Ermenileri, refah seviyelerinin düşmesinin sebebi olarak Osmanlı topraklarından gelen Ermenilerine karşı kin duymuşlardı. ${ }^{22}$

Nitekim raporun tarihi (1921) dikkate alındığında Ermenistan, Bolşeviklerin kurduğu sosyalist bir cumhuriyetle idare edilmektedir. Bu cumhuriyet idaresi altında Ermeniler, Rus Ermenisi ve Türk Ermenisi olarak iki gruba ayrımış durumdadır. Ayrıca raporda Ermenistan'da Müslüman Türklerin varlığı da dikkat çekicidir.

Türkler ile Ermeniler XIX. yüzyıla kadar Kafkasya'da yaşamlarını huzur ve sükûn içinde sürdürmüşlerdi. Fakat bu birliktelik, Rusların bölgeyi istilasına kadar devam etti. ${ }^{23}$ Ruslara cihan hâkimiyeti fikrini aşılayan Deli Petro (Petro/Birinci Pyotr 1721-1725)24 ile başlayan ve II. Katerina (1721-1725) $)^{25}$ ile devam eden Rus yayılmacılığı, Rus Çarı I. Aleksandır'ın 1801'de, Doğu Gürcistan'ı işgal edip Gürcü Guberniyası'nı kurması ile başlamıştı. Rusya ve İran arasında bu tarihten sonra başlayan Güney Kafkasya hâkimiyet mücadelesi, 1806'da Osmanlı-Rus Savaşı'nın 16/28 Mayıs 1812 Bükreş Antlaşması ile sonuçlanmasından sonra Rusya'nın lehine dönmüş ve Rusya, daha etkin bir şekilde İran

\footnotetext{
${ }^{22}$ Rus Imparatorluk Kayıtlarında Ermeni Sorunu (1912-1917), (Çev. ve Yay.Haz.) Natalia Chernichenkina, Erzincan Üniversitesi Yayınları, Erzincan, 2015, s. 77.

${ }^{23}$ Gürcistan, Erivan, Bakü, Gence, Karabağ ve Nahçıvan, III. Murat döneminde 1578'de Lala Mustafa Paşa'nın serdarlığıyla başlayan seferler ve sonrasında 1583 'te Ferhat Paşa tarafından devam ettirilen fetihlerle Osmanlı topraklarına katılmıştır. Revan, 1590 yılında İran ile imzalanan anlaşma sonrası Osmanlı Devleti'nde kalmış IV. Murat dönemine kadar iki taraf arasında sık sık el değiştirmiştir. IV. Murat 1634'te, Revan'ı tekrar Osmanlı topraklarına katmış, ancak 1639 Kasr-ı Şirin Antlaşması ile Revan/Erivan Safeviler'e bırakılmıştır. Bkz. Enes Demir, Azerbaycan, Gürcistan ve Kıbrıs Fatihi Lala Mustafa Paşa, İdeal Kültür Yayınları, İstanbul, 2007, s. 163-207.

24 Beşir Mustafayev, "Cihan Hakimiyetini Moskoflara Öğütleyen Deli Petro'nun Vasiyetnamesi ve Ermenistan Devleti'nin Kurulmasına Etkisi”, Uluslararası Avrasya Sosyal Bilimler Dergisi, 4/11 (Haziran 2013), s. 17-27.

${ }^{25}$ Rus Çariçesi II. Katerina'nın (1762-1796) Kafkasya Ermenilerinden yardım istemesi ile Ermeni Başpiskoposu Josef Argotyan'ın bağımsız bir Ararat Krallığı projesini hazırlayıp Rus Çariçesi'ne sunması Rus-Ermeni işbirliğinde bir dönüm noktası olmuştu. Sabahattin Özel, "Ermenilerin ve Yabancıların Gözüyle Türk-Ermeni Iliş̧kileri ve Ermeni Sorununa Bakış”, Yakın Dönem Türkiye Araştırmaları, 3 (2003), 175-228, s. 180.
}

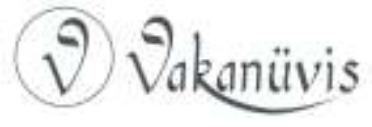


üzerine harekete geçebilmişti. 12 Ekim 1813'de Karabağ'ın Gülistan şehrinde İran ve Rusya arasında Güney Kafkasya toprakları paylaşılmış ve Gülistan Anlaşması'na göre Derbend, Kuba, Bakü, Lenkeran, Şirvan, Şeki, Gence ve Karabağ hanlıkları ile Ilısu Sultanlığı üzerindeki hâkimiyet hakkı Rusya'ya bırakılmıştı. ${ }^{26}$ Böylece Rus-İran mücadelesi, Rusya'nın Revan Hanlığına taarruzuna, İran'ında karşılık olarak Tiflis üzerine saldırmasıyla devam etmişti. Bu saldırılar sonucu İran Şahı, barış istemek zorunda kalmış ve 10 Şubat $1828^{\prime}$ de Rusya ile İran arasında Türkmençay Antlaşması imzalanmıştı. Antlaşmaya göre Revan Hanlığ ${ }^{27}$ ve Nahçıvan Hanlıkları, Rusya'ya bırakılmıştı. ${ }^{28}$ Nitekim Rusya, antlaşmadan sonra Revan Hanlığını ilhak etmiş, burayı Erivan Guberniyası'na (1850) çevirmiş ve gelecekteki Ermenistan'ın ilk adımını atmıştı. Türkmençay Antlaşması'nın 15'inci maddesi gereğince; Güney Azerbaycan'da bulunan halk, istedikleri takdirde Rusya'ya göçebilecek ve bunlara yerleşebilmeleri için uygun şartlar yaratılacaktı. ${ }^{29} 1828$ yılına kadar Erivan ve civarında nüfusun toplamı, 106,900 idi. Bu nüfusun 81,749'u Müslüman Türk, 25,151'i ise Ermenilerden oluşturmaktaydı. ${ }^{30}$ Oran olarak bakıldığında ise \% 76,47 Türk, \% 23,53'ü ise Ermeni idi. 1826-1828 İran-Rus savaşı esnasında ise İran'dan Kafkasya'ya 18,000 Ermeni ailesi gelmiş, Türkmençay Antlaşması ile de 1828-1830 yılları arasında İran'dan 40,000, Osmanlı ülkesinden ise yaklaşık 84,000-100,000 ${ }^{31}$ arasında Osmanlı Ermenisi,

${ }^{26}$ Osmanlı Devleti Ile Azerbaycan Türk Hanlıkları Arasındaki Münasebetlere Dair Arşiv Belgeleri (1578-1914), Osmanlı Devlet Arşivleri Genel Müdürlüğü Yayınları, Yayın Nu. 4, Ankara, 1992, s. 39.

27 XIX. yüzyıl başlarında Revan Hanlığı; Kırkbulak, Zengibasar, Gernibasar, Vedibasar, Şerur, Sürmeli, Derekend-Parçanis, Körpübasar, Abaran, Dereçiçek ve Göyçe mahallerinden oluşmaktaydı. Hanlığın merkezi Revan/Erivan şehriydi. Yavuz Aslan, “Rus İstilasından Sovyet Ermenistanı'na Erivan(Revan) Vilayeti'nin Demografik Yapısı (1827-1922)", Yeni Türkiye Dergisi Ermeni Özel Sayısı, 4/63 (2014), s. 2611.

${ }^{28}$ Ali Kafkasyalı, "Ali Şenlik'in Revan Seferi ve Zehirlenerek Öldürülmesi”, A.Ü. Türkiyat Araştırmaları Enstitüsü Dergisi, 25 (2004), s. 107-120.

29 Okan Yeşilot, "Türkmençay Antlaşması ve Sonuçları", A.Ü. Türkiyat Araştırmaları Enstitüsü Dergisi, 36 (2008), s. 187-199.

30 Oktay Kızılkaya, "Günümüz Ermenistan Coğrafyasında Türk Nüfusun Tarihi Süreçteki Durumu", Yeni Türkiye Dergisi, 63 (2014), s. 2599-2609.

31 Kemal Beydilli, “Osmanlı-Rus Savaşı'nda Doğu Anadolu'dan Rusya'ya Göçürülen Ermeniler", Belgeler, XIII/17 (1988), s. 410.

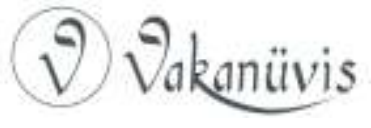


Tiflis, Gence ve Erivan bölgesine yerleştirilmişti. ${ }^{32}$ Nitekim Rusya'nın Kafkasya'yı Ermenileştirmesi, XX. yüzyılın başlarına kadar devam etmiş ve bu kapsamda yaklaşık 1.300,000 Ermeni Kafkasya'ya göç ettirilmişti. ${ }^{33}$ Dolayısıyla bölgede Ermeni nüfusu hızla artarken göçler, katliamlar ve siyasi baskılar yüzünden bölgede bulunan Müslüman Türk nüfusu da sürekli olarak azalmıştı. Nitekim 1914 yılında Erivan Vilayetindeki Müslüman Türk nüfusu, 270,0004 iken 1922 yılı itibariyle bu sayı, 72,596'ya düşmüştü. ${ }^{35}$ Sonuç olarak $1828^{\prime}$ den başlamak üzere Erivan bölgesinde Müslüman Türk nüfusu azalmış, Ermeni nüfusu ise artış göstermişti.

Yüzbaşı Bahattin Bey'in raporunun son kısmında ise, Ermenistan'da ki sosyo-ekonomik hayata dair bilgiler bulunmaktadır. Buna göre;

Dükkanların kısm-ı azamı (çoğu) kapalıdır. Maneviyat pek bozuktur. Nahçıvan telsizinin Nahçıvan'da mukabil inkılâp başladığı haftada Bakü'ye verdiği bir haber, bura telsizi tarafından çalınmış bununda gazetelerle ilanı maneviyatı biraz takviye etmiştir. Şehirde ekmek et bulunmuyor. Hükümet cevabI zazuriyeye tarh (vergi) koymuş ve bundan dolayı her şeyi gizlemiştir. Mamafih, hali tabii avdet etmesiyle Ermenistan kendisini iki ay beslemeyebilir. Bu sene ziraatta muntazam olamayacağından müthiş bir kıtlık hüküm ferma olacağını zan ediyorum. Burada pek mebzul (bol) olan pirinç bir put (1 put=16 kg.) bir ay evvel 70.000 ruble iken bugün 250.000 rubleye çıkmıştır. Bir kont (ölçü birimi) gaz 3.000 rubledir. Bütün ümit Nahçıvan yolunun açılmasında ve Türkiye'nin muavenetindedir. Türkiye Ermenileri Sevr'e göndermeleri için müracaat etmekte (şifrelenmiş) unuttukları Osmanlı tebaası (şifrelenmiş) kemal-i iftiharla (övünç) (şifrelenmiş) Sevr'e bakmaktadırlar.

Rapordan anlaşılacağı üzere dükkânların kapalı olması, halkın canlı bir ekonomik hayattan yoksunluğunu göstermektedir. Ayrıca halk, temel besin maddesi ekmek ve etten dahi yoksundur. Dolayısıyla

\footnotetext{
32 Nigar Gözelova, "Rus İmparatorluğunun Dış Politikası ve XIX. Yüzyılın Başlarında İrevan Hanlığı'nda Etnodemografik Durumun Değişmesi”, Yeni Türkiye Dergisi, 63 (2014), s. 2625.

33 Yeşilot, a.g.m., s. 192.

34 Justin Mc Carthy, Ölüm ve Sürgün, Çev. Bilgi Umar, İnkılap Kitabevi, İstanbul, 1988, s. 256.

${ }^{35}$ Aslan, a.g.m., s. 2610-2620.
}

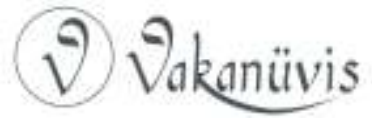


Ermenistan bölgesinde kıtlık yaşanmakta ve bu durum halk üzerinde maneviyat bozukluğuna sebebiyet vermiştir. Ayrıca Nahçıvan'da karşıdevrim (Bolşevik muhalefeti) hareketleri vardır. Buna göre Ermenistan'da iç savaş devam etmektedir. Raporda fiyatların çok yüksek olması karşılaştırılmalı olarak verilmiş ve durumun vahameti ortaya konulmuştur. Ziraî faaliyetler azdır ve kıtlığa sebebiyet vereceği değerlendirilmiştir. Hükümet, gelirlerini artırmak için vergilerin artırılması yoluna gitmiştir. Rapora göre, bu olumsuz hava karşısında halk, Nahçıvan yolunun açılması ile canlanacak olan ticari faaliyetlere ve Türkiye'den gelecek yardımlara umut bağlamıştır.

Dönemin ekonomik koşulları incelendiği zaman 1921-1922 yılları arasında Bolşevik Rusya'da Bolşevik İhtilali'nin yerleştirilmesi mücadelesi devam ederken dönemin en büyük kıtlığı yaşanmaktadır. Buna göre Bolşevik Rusya'da kıtlıktan bu dönemde yaklaşık 13 milyon insan hayatını kaybetmiştir. ${ }^{36}$

Bunların yanı sıra Kars Antlaşması ile Azerbaycan'a bağlı özerk bir devlet haline gelmiş olan Nahçıvan hakkında bilgi vermek gerekmektedir. Buna göre raporun tarihi dikkate alındığında Nahçıvan'ın statüsünün henüz belirlenmediği bir dönemdir. ${ }^{37}$ Evliya Çelebi'nin Nakş-i Cihân (dünyanın süsü) olarak adlandırdığı Nahçıvan ${ }^{38}$, 1828 Türkmençay Antlaşması ile Rusya'ya bırakılmıştı. 1917 Bolşevik intilali ile yönetimi ele geçiren Bolşevikler, Rusya toprakları içerisinde bulunan bütün milletlere bağımsız devletler kurma hakkı dâhil kendi kaderlerini serbestçe tayin etme hakkı vermişti. ${ }^{39}$ Nitekim Osmanlı

\footnotetext{
${ }^{36}$ Alper İpek, "Sovyetler Birliği'nin Dağılması Karşısında Sovyet İnsanının Tepkisizliğinin Nedenleri", Savunma Bilimleri Dergisi, 14/1 (Mayıs 2015), s. 89-118.

37 Raporun tarihi, 16 Mart 1921'dir, Kars Antlaşması ise 21 Ekim 1921 tarihinde imzalanmıştır. Dolayısıyla Nahçıvan'ın statüsünün kesinleşmesine yaklaşık yedi ay vardır.

38 Hüsamettin M. Karamanlı, "Nahçıvan", İslam Ansiklopedisi, 32 s. 295, http://www. diyanetislamansiklopedisi.com/ nahcivan/, [Erişim Tarihi: 22.01.2021]

39 Erel Tellal, "Mir Sultan Galiyev", Ankara Üniversitesi SBF Dergisi, 56/1 s. 107, http://dergiler.ankara.edu.tr/dergiler/42/470/5402.pdf, [Erişim Tarihi: 22.01.2021] s. 107, ABD Başkanı Woodrow Wilson 8 Ocak 1918 tarihli Kongre toplantısında 14 maddelik ilkelerini sıralamıştı. Buna göre ilkelerin 5'inci maddesi halkların istekleri ve çıkarları doğrultusunda sömürge devletlerinin eşitlikçi ve hakkaniyetli düzenlemeler yapmasını tavsiye ediyordu. Dolayısıyla bu maddenin hem ekonomik, hem askeri, hem
}

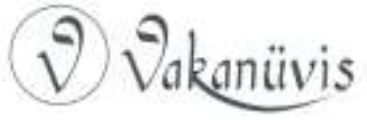


ordusunun Mondros Mütarekesi ile silah bırakması ve bu bölgeden çekilmesinden sonra burada Nahçıvan merkez olmak üzere Aras Cumhuriyeti kurulmuştu. ${ }^{40}$ Nahçıvan hanlarının neslinden olanların yönettiği Aras Cumhuriyeti; Nahçıvan, Şerûr-Dereleyez kazaları, Ordubâd, Culfa, Megri, Vedibasar, Kamerli şehirlerini içine alıyordu. Askerî yardım amacıyla Halil Bey'in liderliğinde beş subay ve 300'den fazla er emekliye ayrılıp çeşitli meslek sahibi olarak Aras Cumhuriyeti'nin ayrı ayrı bölgelerine yerleştirilmişti. Fakat 12 Nisan 1919 'da İngilizler, Nahçıvan'da parlamento binasını basarak hükümet faaliyetlerine son verip, üyelerini sürgüne göndermişlerdi. ${ }^{41}$ Ingilizler ise bu bölgede sadece demiryolu hattını kontrol edebilmişlerdi. Halkın yoğun tepkileri karşısında Nahçıvan'dan çekilen İngilizler 'in yerine bu defa bölgeye Amerikalılar gelmişlerdi. ABD temsilcileri, Nahçıvan'da yönetimi ele geçirmek için yerli milliyetçiler, musâvatçılar, Taşnaklar ve Türkiye temsilcisi Halil Bey ile Nahçıvan'ın statüsü üzerine görüşmeler yapmıştı. ${ }^{42}$ Ancak 27 Nisan 1920'de Azerbaycan'ın Sovyet Rusya tarafından işgali ile İtilaf Devletleri'nin Güney Kafkasya'daki hâkimiyeti de sona ermişti. Bu tarihten sonra Ermenistan ve Azerbaycan arasındaki toprak anlaşmazlıklarını çözecek tek güç Sovyet Rusya olmuştu. Ermenistan'da Sovyet hâkimiyeti kurulduktan sonra Josef Stalin tarafından önceden hazırlanan plan doğrultusunda Azerbaycan Komünist Partisi Siyasi Bürosu, 30 Kasım 1920 tarihinde Nahçıvan ve Zengezur bölgelerinin Ermenistan'a verilmesiyle ilgili olarak özel bir karar kabul etmişti. Bu karara göre 1921 yılında Zengezur bölgesi iki cumhuriyet arasında bölünmüş ve nitekim Azerbaycan'a ait yaklaşık 4,500 km²'lik alan Ermenistan'a verilmişti. ${ }^{43}$ Esasen Rusya'nın bu kararı üzerinde Kâzım Karabekir Paşa'nın yürütmüş olduğu Doğu Cephesi

de ideolojik boyutları bulunmaktaydı. Insan Şerif Kaymaz, "Wilson Prensipleri ve Liberal Emperyalizm", Atatürk Araştırma Merkezi Dergisi, 23/67-69 (2007), s. 151.

40 Selma Yel, Yakup Şevki Paşa ve Askeri Faaliyetleri, Atatürk Araştırma Merkezi Yayınları, Ankara, 2002, s. 90.

${ }^{41}$ Nazim Kahramanov, "Aras Türk Hükümetinin Kuruluşu”, IRS Tarih Bilinci, 2/10 (Yaz 2014), s. 39.

42 Karamanlı, a.g.e., s. 295.

43ilgar Vahitoğlu Nifteliyev, "1918-1920 Yıllarında Ermenilerin Erivan Bölgesinde Azerbaycan Türklerine Karşı Yaptıkları Soykırım ve Azerbaycan'la İlgili İddiaları", Yeni Türkiye Dergisi, 63 (2014), s. 2637.

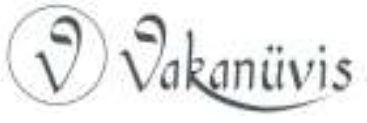


Harekâtının etkisi vardı. ${ }^{44}$ Nitekim 28 Eylül 1920'de başlayan harekât sonucunda 15. Kolordu Kumandanı Kâzım Karabekir Paşa, Gümrü'ye kadar ilerlemişti. Bunun üzerine Ermenistan Hükümeti ateşkes istemiş ve Türkiye-Ermenistan arasında 2/3 Aralık 1920'de Gümrü Antlaşması imzalanmıştı. ${ }^{45}$ Gümrü Antlaşması'nın 2. ve 12. maddeleri Nahçıvan ile ilgilidir. ${ }^{46}$ Antlaşma sonucunda Şerur, Şahtahtı ve Nahçıvan bölgelerinde şimdilik Türkiye'nin himayesi altında mahalli yönetim oluşturulacak ve bu bölgenin yönetim şekli ve sınırları seçim yoluyla belirleninceye kadar Ermenistan buraya karışamayacaktı. ${ }^{47}$ Nitekim 1921 'de Nahçıvan'da bir referandum yapılmış ve halk, Nahçıvan'ın özerk cumhuriyet statüsünde Azerbaycan'a bağlı kalmasını tercih etmişti. 16 Mart 1921'de imzalanan Moskova Antlaşması ile de Nahçıvan'a özerklik statüsü verilerek Azerbaycan Sovyet Sosyalist Cumhuriyeti'ne bağlanmıştı. Son olarak da 13 Ekim 1921'de Türkiye ile Sovyet Sosyalist Cumhuriyetleri (Gürcistan, Ermenistan ve Azerbaycan) arasında Kars Antlaşması yapılmış ve Nahçıvan, Azerbaycan'a bağlı özerk bir bölge olarak kalmıştı. ${ }^{48}$

Yüzbaşı Bahaeddin Bey'in raporunun tarihi (16 Mart 1921) dikkate alınırsa Nahçıvan'ın statüsü henüz belirlenmektedir. ${ }^{49}$ Diğer bir deyişle referandumun resmiyet kazanması ve Gümrü Antlaşması'nın tasdik edilmesi beklenmektedir. ${ }^{50}$ Raporda geçen Nahçıvan yolu, Bolşevik

\footnotetext{
${ }^{44}$ Türk Istiklal Harbi Doğu Cephesi 1919-1922, Gnkur. Basımevi, Ankara, 1965, s. 92.

45 Abdurrahman Bozkurt, "Osmanlı Devleti ile Ermenistan Cumhuriyeti Arasındaki İlişkiler (1918-1920)", OTAM, 34 (Güz 2013), s. 52.

46 Ibrahim Ethem Atnur, Osmanlı Yönetiminden Sovyet Yönetimine Kadar Nahçıvan 1918-1922, Türk Tarih Kurumu, 2001, s. 401.

47 Nifteliyev, a.g.m., s. 2637.

${ }^{48}$ ismail Hacıyev, "Nahçivan: Ermeni İddiaları ve Tarihi Gerçekler", http://www.ayk.gov.tr/wp-content/ uploads/2015/01/HACIYEV-i̇smail-NAHÇIVANERMENI-IDDIALARI-VE-TARIHI-GERÇEKLER.pdf, [Erişim Tarihi: 25.01.2021]

${ }^{49} \mathrm{Bu}$ tarih ayrıca Türkiye-Sovyet Rusya arasında yapılan Moskova Antlaşması'nın tarihidir.

50 Gümrü Antlaşması'ndan sonra Sovyet Rusya-Türkiye arasında 16 Mart 1921'de Moskova Antlaşması yapılmıştır. Sonrasında ise "1921 Türkiye ile Ermenistan, Azerbaycan ve Gürcistan Arasında Dostluk Antlaşması" başlığını taşıyan Kars Antlaşması, Moskova Antlaşması hükümlerinin Kafkas Cumhuriyetlerince de onaylanmasını sağlamak amacıyla yapılmıştı. Nitekim antlaşma sonucunda TürkiyeErmenistan sınırında herhangi bir değişiklik yapılmamış, Moskova Antlaşması'nda belirlenen hususlar, Kars Antlaşması'nın da esasını oluşturmuştu. Mehmet Okur,
}

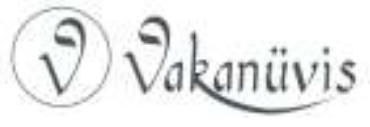


Rusya'nın Türk İstiklal Harbi döneminde Anadolu’ya yardım gönderdiği Şahtahtı-Nahçıvan Demiryoludur. ${ }^{51}$ Yol, raporun tarihi itibariyle kapalıdır. Esasen Gümrü Antlaşması'nın 12. maddesi gereğince yol, Ermenilere açılmıştı. Fakat Ermenilerin demiryolunu kullanması hususunda sıkı tedbirler uygulanmaktaydı. Zira Bolşevik Ermeni liderleri, Gümrü Antlaşması'nı tanımadıklarını ilan etmişlerdi. ${ }^{52}$

Son olarak Yüzbaşı Bahaeddin Bey'in raporunda, Sevr Antlaşması'na atıf yapılmaktadır. Bilindiği üzere Ermenistan Cumhuriyeti, Paris Barış Konferansı'na temsilciler göndermiş ve Osmanlı topraklarında bir Ermeni devleti kurulması için taleplerde bulunmuşlardı. ${ }^{53}$ Nitekim Sevr Barış Antlaşması'nın 88.-93. maddeleri ile masa başında Doğu Anadolu bölgesinde bir Ermeni devleti kurulmuştu. ${ }^{54}$ Rapordan da anlaşılacağı üzere Ermeniler bundan övünç duymaktadır. Osmanlı Hükümeti bu antlaşmayı 10 Ağustos 1920'de imzalamıştı. Fakat Anadolu'da Mustafa Kemal Paşa önderliğinde başarılı bir harekât yürüten Ankara Hükümeti, antlaşmayı kabul etmemişti. Buna göre ìstanbul Hükümeti, İtilaf Devletleri'ne Anadolu Müzâkerâtı'ndan ${ }^{55}$ dolayı antlaşmanın tasdik edilmediğini ve bundan sonra uygulanmayacağını ${ }^{56}$ bildirmek zorunda kalmıştı. Raporda dikkat çeken diğer bir husus ise Ermenistan Cumhuriyeti ve Ermenilerin Osmanlı Devleti'nden toprak taleplerine rağmen Türkiye'den yardım bekledikleridir.

“Gümrü, Moskova ve Kars Antlaşmaları Çerçevesinde Ermeni Sorunu Üzerine Genel Bir Değerlendirme", Kafkas Üniversitesi Sosyal Bilimler Enstitüsü Dergisi, 8 (Sonbahar 2011), s. 84.

${ }^{51}$ Cemal Avcı, "Milli Mücadele'de Türk-Ermeni ve Gürcü Ilişkileri”, Atatürk Yolu Dergisi, 4/13 (1994), s. 5.

52 Atnur, a.g.e., s. 406.

53 Salahi R. Sonyel, Türk Kurtuluş Savaşı ve Dış Politika, C.I, TTK Basımevi, Ankara, 1995, s. 21.

${ }^{54}$ Bilal N. Şimşir, Ermeni Meselesi 1774-2005, Bilgi Yayınevi, Ankara, 2005, s. 428-429.

${ }^{55}$ Sevr Barış Antlaşması'nın Ankara Hükümetine kabul ettirilmesi için Ahmet İzzet Paşa başkanlığında bir heyet, 3 Aralık 1920'de Bilecik'te Mustafa Kemal Paşa başkanlığında Ankara Hükümeti temsilcileri ile bir araya gelmişti. Fakat İstanbul'dan gelen heyet, Ankara heyeti tarafından Ankara'ya götürülerek alıkonulmuştu. Hakan Türker, "Tevfik Paşa Hükûmetinin Anadolu ile Uzlaşma Arayışı ve Bilecik Buluşmasının Basındaki Yansımaları (1920)", Çağdaş Türkiye Tarihi Araştırmaları Dergisi, 17/34 (2017), s. 6995.

56 MSB ATASE Arşivi, İstiklal Harbi Koleksiyonu, Kutu: 990, Gömlek: 60 (31 Aralık 1920).

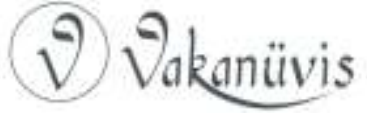


Sonuç olarak 1921 yılı, Anadolu'da Türk ordusunun Yunan ordusuna karşı başarılı muharebeleri yürüttüğü bir yıldır. Buna göre 9-11 Ocak 1921 'de I. İnönü Muharebesi, 23 Mart-1 Nisan 1921'de II. İnönü Muharebesi ve 23 Ağustos-13 Eylül 1921'de Sakarya Meydan Muharebesi yapılmıştır. Nitekim Türk İstiklal Harbi'nin zaferlerle dolu bu muharebeleri ile Ermenistan Cumhuriyeti'nin ve Ermenilerin Sevr beklentileri akamete uğratılmıştı.

\section{Sonuç}

Bu çalışmada Erivan Türk Mümessilliğinde görevli Yüzbaşı Bahaddin Bey'e ait bir rapor, tarih tenkidinin unsurları kapsamında incelenmeye çalışıımıştır. Buna göre raporun tarihi 16 Mart 1921 olup yazarı murahhas Yüzbaşı Bahaeddin Bey'dir. Raporun yazıldığı yer Iğdır, yazan makam Erivan Türk Mümessilliği, raporu alan makam ise Nahçıvan'da bulunan Şahtahtı Müfrezesidir. Raporun iç tenkidi kapsamında ise raporda geçen bilgiler, dönemin olayları ile karşılaştırılmıştır. Bu kapsamda Ermenilerin dini inançları, Bolşevik ideolojinin Ermenistan'da yayılmacılığı ve halk üzerindeki etkisi, Ermenistan'ın nüfusu, sosyal yapısı ve bu yapı içindeki mevcut ayrılıklar, Ermenistan'ın ekonomik durumu, Nahçıvan'ın statüsü ve Ermenilerin Sevr Barış Antlaşması'na karşı bakış açıları ortaya konulmaya çalışıımıştır.

Sonuç olarak 16 Mart 1921 tarihli bu rapor, tarihi bir vesika özelliği taşımaktadır. Vesika, tarih tenkidinin unsurları (iç tenkit ve dış tenkit) kapsamında incelenmiş ve vesikada geçen olaylar, dönem itibariyle doğrulanmıştır(sahih). Bunların yanı sıra vesikanın dönemin Ermenistan'ı hakkında önemli bilgiler vermesi, vesikayı ayrıca değerli kılmıştır. 


\section{Kaynakça}

\section{A. Arşiv Kaynakları}

MSB ATASE Arşivi

1022/113, 990/60, 765/77, 76/64, 760/64aa, 1022/123, 756/77.

\section{Başkanlık Osmanlı Arşivi}

BOA, HR-HMŞ-işO,231-80-1-1.

\section{B. Araştırma Eserler ve Yayınlar}

Arslan, Ali, “I. Dünya Savaşı Sonunda Nahçıvan'da Yapılan Milli Mücadele ve Bugünkü Nahçıvan'ın Statüsünün Oluşumu", Atatürk Araştırma Merkezi Dergisi, XIV/41 (Temmuz 1998).

Aslan, Yavuz, "Rus İstilasından Sovyet Ermenistanı'na Erivan(Revan) Vilayeti'nin Demografik Yapısı (1827-1922)", Yeni Türkiye Dergisi Ermeni Özel Sayısı, 4/63(2014).

Atnur, İbrahim Ethem, Osmanlı Yönetiminden Sovyet Yönetimine Kadar Nahçıvan 1918-1922, Türk Tarih Kurumu, 2001.

Avcı, Cemal "Milli Mücadele'de Türk-Ermeni ve Gürcü Illişkileri", Atatürk Yolu Dergisi, 4/13 (1994).

Beydilli, Kemal, “Osmanlı-Rus Savaşı'nda Doğu Anadolu'dan Rusya'ya Göçürülen Ermeniler”, Belgeler, XIII/17 (1988).

Bıyıklığlu, Tevfik, Osmanlı-Türk Doğu Hudut Politikası, Milli Savunma Akademisi (Basılmamış daktilo eser ATASE Kütüphanesi), İstanbul, ,1958.

Bozkurt, Abdurrahman, "Osmanlı Devleti ile Ermenistan Cumhuriyeti Arasındaki Ilişkiler (1918-1920)", OTAM, 34 (Güz 2013).

Çakı, Caner, "Ermenistan Sovyet Sosyalist Cumhuriyeti'nde Joseph Stalin Döneminde Kullanılan Sovyet Propaganda Posterleri Üzerine İnceleme", Ermeni Araştırmaları Dergisi, 61 (2018).

Demir, Enes, Azerbaycan, Gürcistan ve Kıbrıs Fatihi Lala Mustafa Paşa, İdeal Kültür Yayınları, İstanbul, 2007.

Develioğlu, Ferit, Osmanlıca-Türkçe Sözlük, Aydın Kitabevi, Ankara, 2002.

Gözelova, Nigar, "Rus İmparatorluğunun Dış Politikası ve XIX. Yüzyılın Başlarında İrevan Hanlığı'nda Etnodemografik Durumun Değişmesi”, Yeni Türkiye Dergisi, 63 (2014).

Hacıyev, İsmail, "Nahçivan: Ermeni İddiaları ve Tarihi Gerçekler", http://www.ayk.gov.tr/wp-content/uploads/2015/01/HACIYEV-İsmail-

NAHÇIVAN-ERMENI-IDDIALARI-VE-TARIHI-GERÇEKLER.pdf, [Erişim Tarihi: 25.01.2021]

Halkın, Leon-E., Tarih Tenkidinin Unsurları, Çev. Bahaeddin Yediyıldız, Türk Tarih Kurumu Yayınları, Ankara, 2014.

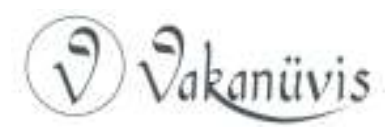


İpek, Alper, "Sovyetler Birliği'nin Dağılması Karşısında Sovyet İnsanının Tepkisizliğinin Nedenleri", Savunma Bilimleri Dergisi, 14/1 (Mayıs 2015).

İskefiyeli, Zeynep, "Ermeni Kimliğinin Oluşumunda Din Faktörü: Hıristiyanlık, Kilise ve Misyonerler", Akademik Incelemeler Dergisi, Sakarya Üniversitesi, II/1 (2007).

Kafkasyalı, Ali, "Ali Şenlik'in Revan Seferi ve Zehirlenerek Öldürülmesi", A.Ü.Türkiyat Araştırmaları Enstitüsü Dergisi, 25 (2004).

Kahramanov, Nazim, "Aras Türk Hükümetinin Kuruluşu", iRS Tarih Bilinci, 2/10 (Yaz 2014).

Karamanlı, Hüsamettin, M. "Nahçıvan", İslam Ansiklopedisi, 32 s. 295, http://www. diyanetislamansiklopedisi.com/ nahcivan/[Erişim Tarihi: 22.01.2021].

Kaymaz, İhsan Şerif, "Wilson Prensipleri ve Liberal Emperyalizm”, Atatürk Araştırma Merkezi Dergisi, 23/67-69 (2007).

Kızılkaya, Oktay, "Günümüz Ermenistan Coğrafyasında Türk Nüfusun Tarihi Süreçteki Durumu", Yeni Türkiye Dergisi, 63 (2014).

Küçük, Abdurrahman, Ermeni Kilisesi ve Türkler, Ocak Yayınları, Ankara, 1997.

Kütükoğlu, Mübahat S., Tarih Araştırmalarında Usul, Türk Tarih Kurumu Yayınları, Ankara, 2014.

McCarthy, Justin, Ölüm ve Sürgün, Çev. Bilgi Umar, İnkılap Kitabevi, İstanbul, 1988.

Mustafayev, Beşir, "Cihan Hakimiyetini Moskoflara Öğütleyen Deli Petro'nun Vasiyetnamesi ve Ermenistan Devleti'nin Kurulmasına Etkisi", Uluslararası Avrasya Sosyal Bilimler Dergisi, 4/11 (Haziran 2013).

Nifteliyev, Ilgar Vahitoğlu, "1918-1920 Yıllarında Ermenilerin Erivan Bölgesinde Azerbaycan Türklerine Karşı Yaptıkları Soykırım ve Azerbaycan'la Ilgili Iddiaları", Yeni Türkiye Dergisi, 63 (2014).

Okur, Mehmet, "Gümrü, Moskova ve Kars Antlaşmaları Çerçevesinde Ermeni Sorunu Üzerine Genel Bir Değerlendirme", Kafkas Üniversitesi Sosyal Bilimler Enstitüsü Dergisi, 8 (Sonbahar 2011).

Osmanlı Devleti ile Azerbaycan Türk Hanlıkları Arasındaki Münasebetlere Dair Arşiv Belgeleri (1578-1914), Osmanlı Devlet Arşivleri Genel Müdürlüğü Yayınları, Yayın Nu. 4, Ankara, 1992.

Özel, Sabahattin, "Ermenilerin ve Yabancıların Gözüyle Türk-Ermeni Iliş̧kileri ve Ermeni Sorununa Bakış", Yakın Dönem Türkiye Araştırmaları, 3 (2003).

Seyfeli, Canan, "Surp Krikor Lusavoriç: Ermenilerin Aydınlatıcısı", Uluslararası Türk Dünyası Inanç Önderleri Kongresi, Ankara, 2002.

Sonyel, Salahi R.i Türk Kurtuluş Savaşı ve Dış Politika, C.I, TTK Basımevi, Ankara, 1995.

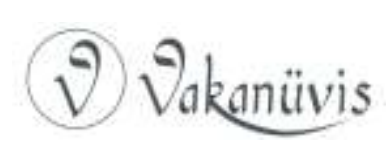


Şimşir, Bilal N., Ermeni Meselesi 1774-2005, Bilgi Yayınevi, Ankara, 2005.

Tellal, Ereli "Mir Sultan Galiyev", Ankara Üniversitesi SBF Dergisi, 56/1 s. 107, http://dergiler.ankara.edu.tr/dergiler/42/470/5402.pdf, [Erişim Tarihi: 22.01.2021].

Tural, Mehmet Akif, “ikinci Dünya Savası Sırasında ve Bitişinde Türkiye'nin Ekonomisi", Prof.Dr.Abdurrahman Güzel Armağanı, Akçağ.

Turan, Ömer, “Bolşevik İhtilali'ni Takip Eden Günlerde Kuzey Kafkasya'da Bağımsızlık Hareketleri ve Yusuf Ercan'ın Sohum Müfrezesi Hatıraları”, Askeri Tarih Bülteni, 40 (1996).

Türk İstiklal Harbi Doğu Cephesi 1919-1922, Gnkur. Basımevi, Ankara, 1965.

Türker, Hakan, "Tevfik Paşa Hükûmetinin Anadolu Ille Uzlaşma Arayışı ve Bilecik Buluşmasının Basındaki Yansımaları (1920)", Çağdaş Türkiye Tarihi Araştırmaları Dergisi, 17/34 (2017).

Yel, Selma, Yakup Şevki Paşa ve Askeri Faaliyetleri, Atatürk Araştırma Merkezi Yayınları, Ankara, 2002.

Yeşilot, Okan "Türkmençay Antlaşması ve Sonuçları", A.Ü. Türkiyat Araştırmaları Enstitüsü Dergisi, 36, (2008).

\section{Elektronik Kaynaklar}

http://www.officespace.am/Unưulhn_umpq/touhuðhl/

http://anitour.am/destinations. php?etchmiadzin

http://ermenikulturu.com/paskalya/

http://www. diyanetislamansiklopedisi.com/ nahcivan/

https://web.archive.org/web/20160303173531/http://www.Parliament.a

$\mathrm{m} /$ parliament.php?id=parliament\&lang=eng 


\section{EKLER}

Ek 1: Erivan Murahhası Yüzbaşı Bahaddin Bey'in Ermenistan Hakkındaki Raporu

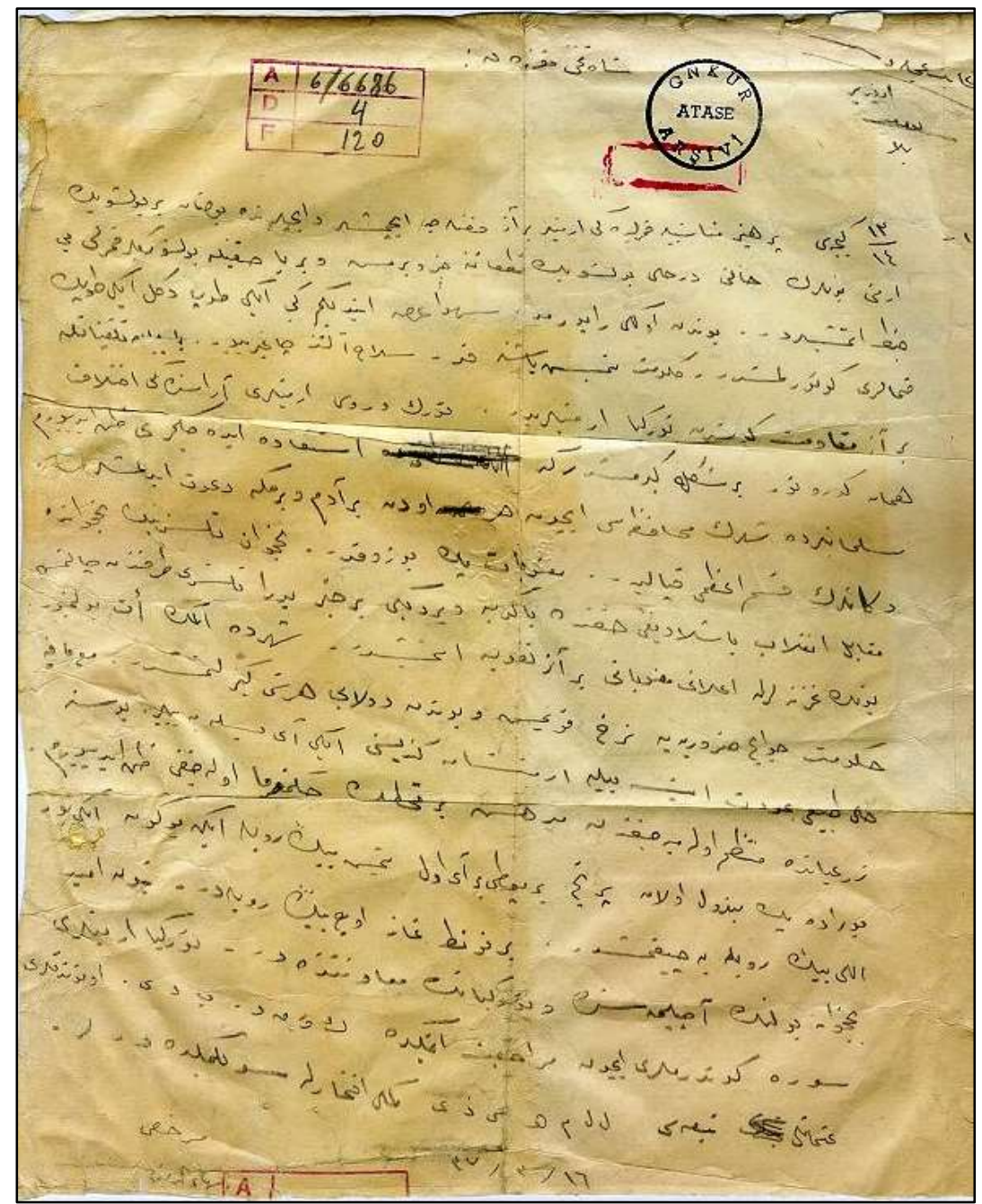

(ATASE, isH-1022-113)

\section{( V) Vakaniuis}

